\title{
Factor Analysis of Physics Chemistry Waters that Affects Damage Safety Cliff on the Outskirts of River Siak
}

\author{
M Dinata ${ }^{1 *}$, F Soehardi $^{2)}$ \\ ${ }^{1 *}$ Faculty of Teachers Training and Education, Universitas Lancang Kuning \\ ${ }^{2}$ Enginering Faculty, Universitas Lancang Kuning \\ *Email : martadinata@unilak.ac.id
}

\begin{abstract}
This research to identify the physics chemistry vegetation of water on the outskirts of the Siak. This research is descriptive condition of vegetation of the safety of the cliff on coasts of siak river. There are fatty oil luminance an observation station and the sulphate high category that ranged $239,50-341,87 \mathrm{mg} / \mathrm{L}$. Followed by the womb chlorida $14,0-24,4 \mathrm{mg} / \mathrm{L}$, phospat 5,31-5,83 $\mathrm{mg} / \mathrm{L}$. With $\mathrm{pH}$ values within the range $6,1-6,8$ in addition to the womb of copper and lead contained in the quality of water made the vegetation that dominated the study areas this is the family of lythraceae and combretaceae that the average is the type of mangrove need phospat high. In the high number of this type of vegetation dominated the outskirts of the river, causing the wall safety a cliff on the outskirts of the river destroyed by aerial roots spread.
\end{abstract}

Keywords : factor analysis, chemistry water, Siak, vegetation, mangrove

\section{Introduction}

The siak descended the river having a very large role in society siak particularly in siak tualang district. The siak provide transportation goods and passengers for the and companies around in the transportation of raw materials and produce connecting cities pekanbaru, district siak and other districts. With a number of activity so as to cause damage to vegetation river, so it needs business damage control river and policies funds requires monitoring the quality of the river. Monitoring is generally was conducted using parameter physical or chemical[1-3]. Recently monitoring with biota more attention, remember biota more firmly in expressing damage river, because biota infected directly river in the long run, and the properties of physical and chemical tending to inform the state of tributary to time measurement. In addition, biota environmentally friendly, cheap, fast and easy description [18]

Pollution can change the structure of ecosystem and reduce the amount of species in a community, so that variety reduced[5-10]. Thus index diversitas ecosystem the tainted always smaller than in natural ecosystem.Diversitas in a waters usually expressed in the number of species that is in the place was influenced by a factor of physics chemistry and water quality [12]

The district government has siak have the commitment of the car to rescue the river siak its industrial activity among others build safety infrastructure in the long term cliffs along along the river bank siak in the form of both of the sheet pile, wire and other, with the concept of the water the front of a city shareholders have blocked an and make visits to the relocation section slum areas banks a river siak, conduct greening program on the ground for more than along the river bank [16]

\section{Experimental Section}

The kind of research this is research descriptive heading for describing it should also be noted the fact the condition of the quality of the water, a discharge of water, intensity of rainfall recently and condition of the erosion of the bluff on the river siak. The necessary data was the data as of primary and secondary. Phases of this study which was conducted is phases of the implementation will be constructed along with preparations were being made for, the literature study, the collection of data, data available for analysis and discussion as well as the conclusion and recommendations.

Preparations were being made for aimed to know the state of the field that is actually and is feasible to be have been used to simplify the guidance after it came of the methodology of residence and the school and various surveys show signs of that is to be performed. It is going to have been 
used to simplify over the withdrawal of funds various surveys show signs of data that will be used and creating a schedule.

Various surveys show signs of time the creatures is the time when the water of a river slipped to only their second pairs of and the time when man binds the streams so slipped to only their second a low tide and to calculate the speed the current of a river made in the condition of man binds the streams so calm and the condition on board with a delicate finish before. Research locations is a cliff river the stream river siak that is in their tualang district to the distance most distant $46 \mathrm{~km}$ from the city of pekanbaru and UPT laboratory health care and the environment.

The results of the testing the measurement of the quality of a water sample a river that obtained then analyzed by the so acquired the condition of a level are prone to air pollution appropriate extent the permission of up to a maximum of which have already been stipulated. The data the speed of water flow in the river use the device sparingly meters and total area of current represents the current, and of cross sectional area water flow in the river. Based on this data later in analysis support for new to be able to determine factors other than a fuel physics chemistry thick in the waters who break the a retaining wall soil and vegetation of herbs on the outskirts of the river siak (Cases in Tualang District Siak).

\section{Results and Discussion}

Based on the research done it was discovered that the not been identified not to factors other than a fuel physics chemistry thick in the waters that affects vegetation of herbs and reports of damage or injuries a retaining wall the ground on the outskirts of the river siak (a case study tualang district Siak) there have been instances of a fatty oil obtained luminance an observation station conceived sulphate high categories all over the place which in total range $239.50-341.87 \mathrm{mg} / \mathrm{l}$. Followed by the moisture content of chlorida 14.0-24.4 mg/l, phospat 5.31-5.83 mg/l (Diagram 1)

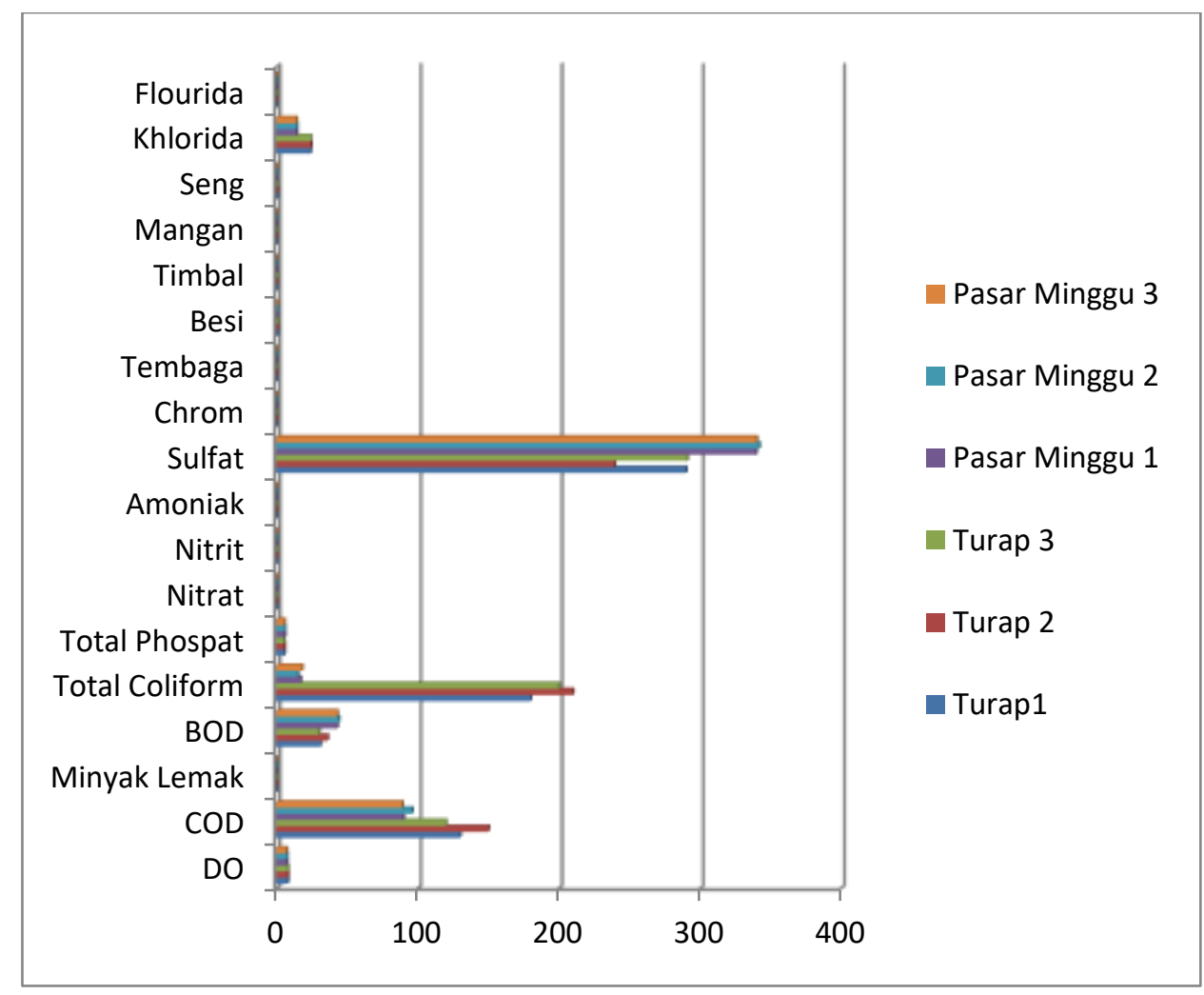

Diagram 1. The Quality of Waters

47 IEKSAKTA: Berkala IImiah Bidang MIPA (Science Periods EKSAKTA of MIPA) 
The research results show that the level of heavy metal crhom, lead, zinc and copper to sample in all locations varies and exceeds the of quality standard set in Indonesia (lead and copper $0.008 \mathrm{mg} / \mathrm{l}$ and crhom $0.001 \mathrm{mg} / \mathrm{l})$. The average levels of metal lead and copper are highest in samples from the area are going to be built to market sunday that is lead range $0.111-0.390 \mathrm{mg} / \mathrm{l}$, followed and she zinc 0.182 $0.515 \mathrm{mg} / \mathrm{l}$ of chemical found it turns out that strengthen the connection dominance vegetation inhabiting the outskirts of river siak.

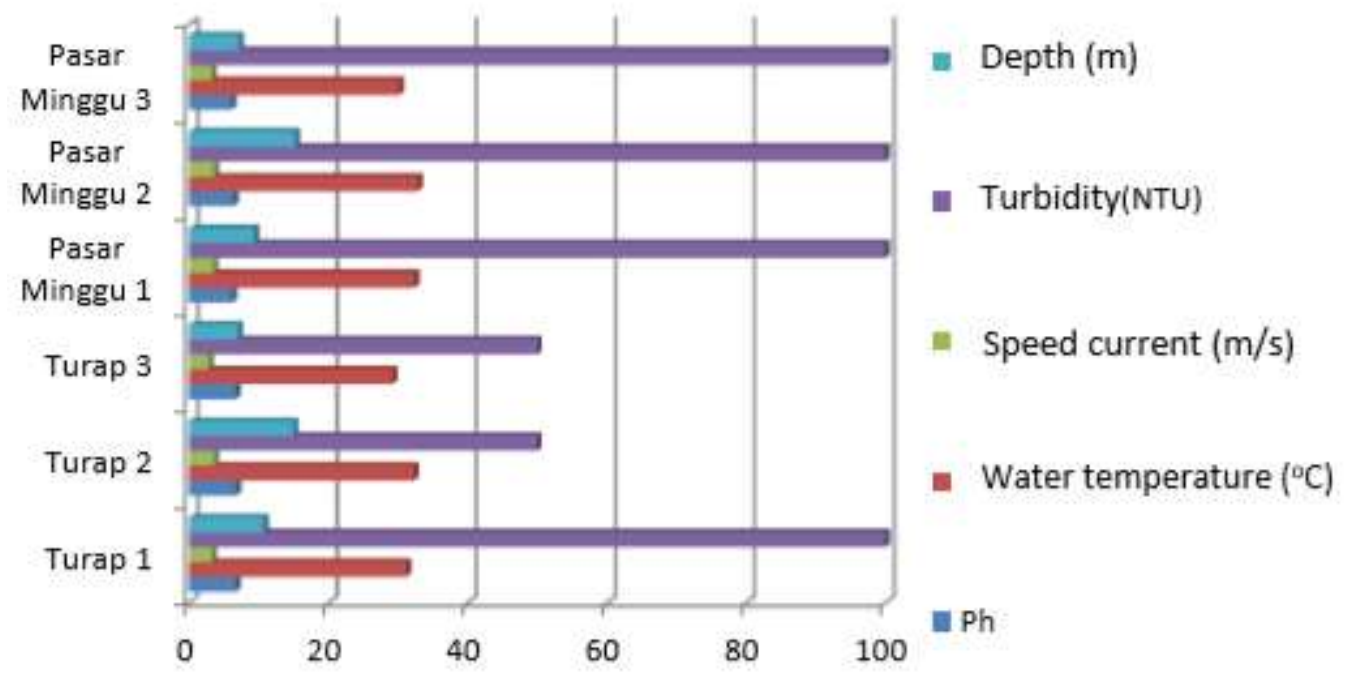

Diagram 2. Physics Chemistry Waters

By the invention of sorts of crops from the family lythraceae and combretaceae dominating of the plaster hits the market outskirts of the siak week. According to Gunarto et.al (2002)[15], the more lead content and his material metal will accelerate salinitas on a rising waters. High salinity is very low affect the growth of family and especially lythraceae combretaceae. The vegetation lythraceae and combretaceae was causing damage retaining walls cliff fringe sungan siak, because of plants from the family has system rooting air spread out of the ground with structure rhizome firm.

\section{Conclusion}

Physics chemistry factors waters that affects vegetation plants and damage a retaining wall land on the outskirts of the river siak (case study tualang district siak) there are fatty oil luminance an observation station and she sulphate high category that ranged $239.50-341.87 \mathrm{mg} / \mathrm{l}$. Followed by the womb klhorida $14.0-24.4 \mathrm{mg} / \mathrm{l}$, phospat $5.31-5.83 \mathrm{mg} / \mathrm{l}$. A kind of vegetation that dominated the study areas this is the family of lythraceae and combretaceae that the average is the type of mangrove need phospat high .In the high number of this type of vegetation dominated the outskirts of the river, causing the wall safety a cliff on the outskirts of the river destroyed by aerial roots spread .

\section{References}

[1] Boy-Roura M, Mas-Pla J, Petrovic M, Gros M, Soler D, et al. 2018. Towards the understanding of antibiotic occurrence and transport in groundwater: Findings from the Baix Fluvia alluvial aquifer (NE Catalonia, Spain). The Science of the total environment 612:1387-406

[2] Castillejo P, Chamorro S, Paz L, Heinrich C, Carrillo I, et al. 2018. Response of epilithic diatom communities to environmental gradients along an Ecuadorian Andean River. Comptes rendus biologies 341:256-63 
[3] Sotomayor G, Hampel H, Vazquez RF. 2018. Water quality assessment with emphasis in parameter optimisation using pattern recognition methods and genetic algorithm. Water research 130:353-62

[4] Alaerts, G. dan S.S. Santika.1984. Metode Penelitian Air. Surabaya: Penerbit Usaha Nasional.

[5] Wan L, Fan X. 2018. Water Quality of Inflows to the Everglades National Park over Three Decades (1985(-)2014) Analyzed by Multivariate Statistical Methods. International journal of environmental research and public health 15

[6] Hale SS, Buffum HW, Hughes MM. 2018. Six decades of change in pollution and benthic invertebrate biodiversity in a southern New England estuary. Marine pollution bulletin 133:77-87

[7] He L, Shen J, Zhang Y. 2018. Ecological vulnerability assessment for ecological conservation and environmental management. Journal of environmental management 206:1115-25

[8] Furley TH, Brodeur J, Silva de Assis HC, Carriquiriborde P, Chagas KR, et al. 2018. Toward sustainable environmental quality: Identifying priority research questions for Latin America. Integrated environmental assessment and management 14:344-57

[9] de Souza Machado AA, Kloas W, Zarfl C, Hempel S, Rillig MC. 2018. Microplastics as an emerging threat to terrestrial ecosystems. Global change biology 24:1405-16

[10] Ruppert JLW, Vigliola L, Kulbicki M, Labrosse P, Fortin MJ, Meekan MG. 2018. Human activities as a driver of spatial variation in the trophic structure of fish communities on Pacific coral reefs. Global change biology 24:e67-e79

[11] APHA. 1998. Standar Method for Examination of Water and Wastewater. 20th ed. New York: American Public Health Association.

[12] Asdak, C. (2007) 'Hidrologi dan Pengelolaan Daerah Aliran Sungai', Gajah Mada University Press, Yogyakarta.

[13] Boyd, C.E. 1999. Code of Practice for Responsible Shrimp Farming. St. Louis, MO.: Global Aquaculture Alliance. Caraco, N., A. Tamse, O. Boutros and I. Valiela. 1978. Nutrient limitation of phytoplankton growth in brack, ish coastal ponds. Canadian Journal Fish Aquatic Science 44: 473-476.

[14] Dudgeon, D. 1992. Endangered Ecosystem: a Review of the Conservation Status of Tropical Asia Rivers. Hydrobiologia 248: 167-191.

[15] Gunarto, A.M. Pirzan, Suharyanto, R. Daud, dan Burhanuddin. 2002. Pengaruh keberadaan mangrove terhadap keragaman makrobenthos di tambak sekitarnya. Jurnal Penelitian Perikanan Indonesia 8 (2): 77-88.

[16] Pirzan, A.M., P.R. Pong-Masak, dan J. Jompa. 2004. Silvofishery sebagai Mata Pencaharian Alternatif di Pulau Bauluang, Kepulauan Spermonde, Sulawesi Selatan. Prosiding Konferensi Nasional IV Pengelolaan Sumber Daya Perairan Umum, Pesisir, Pulau-Pulau Kecil dan Laut Indonesia. Balikpapan. 14-17 September 2004. 